\title{
Congress urged to end budget uncertainty
}

Washington. Ninety US congressmen have signed a letter to the leading members of a budget committee in the House of Representatives calling for immediate agreement on a budget up to the end of the financial year for the National Science Foundation (NSF), the agency that funds most non-biomedical university science.

At present, the foundation has had its funding approved only up to 15 March, a fallout from disagreements between Congress and the Clinton administration. The letter calls on Robert Livingston (Republican, Louisiana), chair of the House appropriations committee, and Jerry Lewis (Republican, Missouri), chair of its subcommittee with jurisdiction over NSF, to "do whatever is possible to provide full-year funding for the NSF as soon as possible".

The letter was circulated last week by Vernon Ehlers (Republican, Michigan), a former research physicist and increasingly prominent defender of science on the House Science committee. It follows an orchestrated barrage of faxes to Congress from scientists in various disciplines drawing attention to NSF's plight.

Several scientific societies tried to rally support for NSF at the end of last month, following a speech from Neal Lane, the director of NSF, in which he criticized "the perceived stony silence" of the research community about the plight of the agency. At that time the NSF had no budget agreed for the 1996 financial year and faced the prospect of yet another shutdown (see Nature 379, 281; 1996).

The immediate threat to NSF was subsequently lifted, but only until March. The scientific societies hope, however, that they have succeeded in raising the profile of the agency, increasing the chances that the NSF will get full-year funding after that, and even improving its funding prospect for next year.

The American Physical Society (APS) contacted all its members by electronic mail two weeks ago, asking them to fax local senators and congressmen with an appeal for funding for NSF. At least 2,000 communications with Congress resulted from this appeal, says Robert Park of the APS.

In addition, a coalition of biologists the American Society for Biochemistry and Molecular Biology, the American Society for Cell Biology (ASCB), the Biophysics Society, the Genetics Society and the American Association of Anatomists - asked the 2,000 members of its "legislative network" to contact the congressional leadership. According to James Bernstein, director of public affairs at the ASCB, more than half responded. "There clearly is a great deal of support for NSF, even from people who are not NSF grantees," says Bernstein.

There is no immediate prospect of the NSF following the National Institutes of Health (NIH) in obtaining a special appropriation that will assure its funding for the rest of the year. But the scientific societies believe that the exercise could mark the beginning of a more effective lobby for the NSF.

Colin Macilwain

\section{Scientific caution 'blunts efforts' to conserve fish stocks}

London. Scientists are partly to blame for the perilous state of the world's fish stocks because their cautiously worded advice has been used by fisheries managers to continue the practice of overfishing, thus endangering the long-term sustainability of stocks, according to a report* published last week by Britain's House of Lords.

The report, prepared by a subcommittee of the Lords' Select Committee on Science and Technology, describes the world's fish stocks as being "in a state of crisis". It calls for broad-based fisheries management panels to help achieve consensus on conserving fish stock and the creation of an International Panel on the Oceans "to help push issues of global concern up the political agenda".

Almost 70 per cent of species are either depleted or being fished at around the maximum sustainable yield, the report says. Yet national catch quotas remain high because of concern about the political implications of unemployment in the fishing industry.

The report says that unless scientists deliver "clear and forceful" advice, governments will continue to sacrifice the longterm sustainability of fish stocks in favour of protecting "short-term" jobs in the fishing industry. "Scientists will always want to draw attention to any degree of uncertainty in their assessments," it says. "But scientific professionalism is currently providing an excuse for political compromise."

The 77-page report also calls for better cooperation between scientists, fishermen, fisheries managers and politicians, more technical measures to improve fish stocks and more aquaculture.

The subcommittee heard evidence from a wide range of witnesses. Some scientists volunteered the view that ambiguous scientific advice may contribute to overfishing, pointing out that the science of fisheries management is not yet firm enough to provide reliable data. Unresolved issues include

\section{IMAGE UNAVAILABLE FOR COPYRIGHT REASONS}

Fish wars: over-fishing has contributed to conflicts between fishermen, including slashed nets

uncertainties about natural variation in fish stocks, including natural mortality, and establishing the correct age in a fish's life when harvesting becomes sustainable.

Organizations such as English Nature and the Joint Nature Conservation Committee told the inquiry that higher quality data are needed if scientific advice is to be relied upon. But others disagreed. Michael J. Holden, former head of the Conservation Unit at the European Commission's Directorate General of Fisheries, who died recently, said politicians are aware that "the scientific basis for formulating fish policy has been available for 60 years". Representatives of Scottish National Heritage also claimed that current scientific methods to provide reliable advice for fish stock management are adequate.

John Shepherd, director of the new Southampton Oceanography Centre, said that the demands being imposed on science are more than it can bear. But he conceded that the International Council for the Exploration of the Sea, the

শ body responsible for carrying out scientific assessments of fish stocks, should "revert to blunter and bolder advice rather than the rather heavily qualified advice" it produces at present.

Lord Butterfield, a member of the subcommittee and a former vicechancellor of the University of Nottingham, said the committee recognized that "unresolved issues in fisheries science" made effective fisheries management more difficult. The committee, he says, also recognized that scientists were constrained by the nature of their training from making value judgements.

"I do understand their dilemmas," says Butterfield. "But who is then going to fill the gap between forming the data and forming opinions?" He adds that scientists "should say clearly that there are certain visible trends, which, if allowed to continue, will lead to catastrophe. I feel if they had said this earlier, it would have had an impact on policy-makers." Ehsan Masood 